\title{
Heat-Shock Response
}

National Cancer Institute

\section{Source}

National Cancer Institute. Heat-Shock Response. NCI Thesaurus. Code C17888.

A constellation of responses that occur when an organism is exposed to excessive heat and other environmental stresses. Responses include synthesis of some proteins, repression of other proteins, and expression of new proteins. (From Segen, Dictionary of Modern Medicine, 1992) 